\title{
The Effectiveness of Cognitive Behavioral Therapy in Group Counselling
}

Yusni Mohamad Yusop, Norsyamimie A. Rahman, Zaida Nor Zainudin, Asmah Ismail, Wan Norhayati Wan Othman, Melati Sumari

To Link this Article: http://dx.doi.org/10.6007/IJARBSS/v10-i9/7648 DOI:10.6007/IJARBSS/v10-i9/7648

Received: 13 June 2020, Revised: 14 July 2020, Accepted: 19 August 2020

Published Online: 23 September 2020

In-Text Citation: (Yusop et al, 2020).

To Cite this Article: Yusop, Y. M., Rahman, N. A., Zainudin, Z. N., Ismail, A., Othman, W. N. W., \& Sumari, M. (2020). International Journal of Academic Research in Business and Social Sciences. 10(9), 359-379.

\section{Copyright: (C) 2020 The Author(s)}

Published by Human Resource Management Academic Research Society (www.hrmars.com)

This article is published under the Creative Commons Attribution (CC BY 4.0) license. Anyone may reproduce, distribute, translate and create derivative works of this article (for both commercial and non-commercial purposes), subject to full attribution to the original publication and authors. The full terms of this license may be seen at: http://creativecommons.org/licences/by/4.0/legalcode

Vol. 10, No. 9, 2020, Pg. 359 - 379 


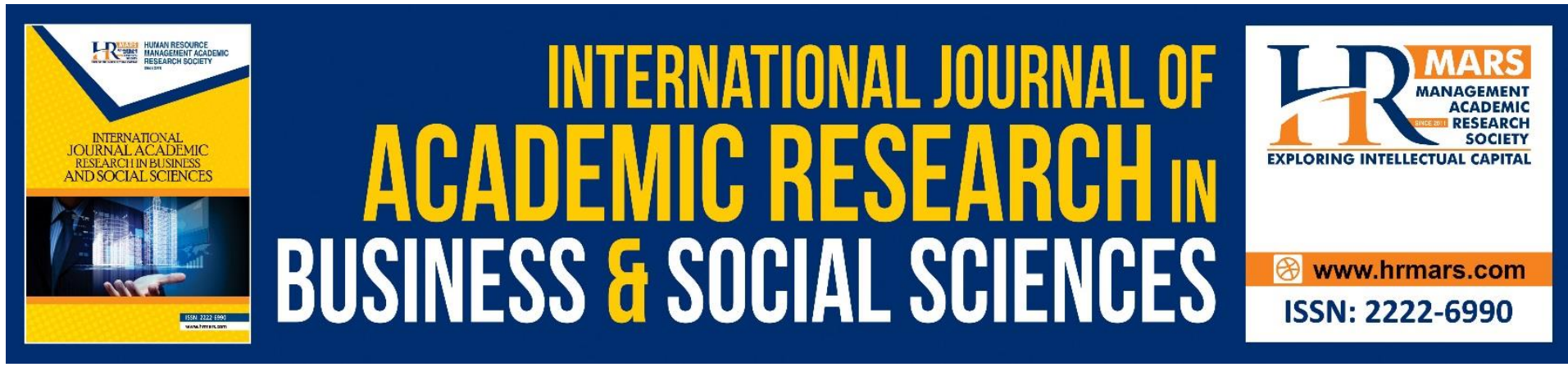

\title{
The Effectiveness of Cognitive Behavioral Therapy in Group Counselling
}

\author{
Yusni Mohamad Yusop (Ph.D), Norsyamimie A. Rahman, \\ Zaida Nor Zainudin (Ph.D), Asmah Ismail (Ph.D), Wan \\ Norhayati Wan Othman (Ph.D), Melati Sumari (Ph.D). \\ $1,2,3,4,5$ Faculty of Educational Studies, University Putra Malaysia, ${ }^{6}$ Faculty of Education, \\ University of Malaya
}

Email:yusni_my@upm.edu.my,gs55362@student.upm.edu.my,zaidanor@upm.edu.my, asmahis@upm.edu.my,wannorhayati@upm.edu.my,melati2112@gmail.com

\begin{abstract}
Counselling is a professional service that required the counselor to use scientific theory for providing effective session with the client. Theory is an important aspect of counselling that which helps the counsellor conceptualize client issues and as a guide for directive session. Cognitive Behavioral Therapy is one of effective treatment that commonly used in wide range of issues. The aim of this review is to identify effectiveness of cognitive behavioral therapy in group counselling. The review is based on Science Direct database from university as a primary literature to search journal articles. The electronic databases used are ProQuest and Google Scholar website also has been utilized. The term "effect", "effectiveness", "cognitive behavioral therapy", "cbt" and "group counselling" as key words are used in the search. 10 journal articles extracted were reviewed. The review found that Cognitive Behavioral Therapy seems to be effective for group counselling session. CBT also give significant improvement for each individual members in group counselling. In conclusion, it is proven that Cognitive Behavioral Therapy approach contribute benefit and effectiveness for group counselling process.
\end{abstract}

Keyword: Cognitive Behavioral Therapy, Cbt, Group Counselling, Effectiveness, Effects.

\section{Introduction}

Counselling is an art of listening to the client, understanding the client's life challenges and collaborating with the client to strategize for change and growth (Ivey, Ivey, \& Zalaquett, 2014). It is a professional service that involve interactions in order to understand or untangle thoughts, situation or feelings. Counsellors, whether trainee or registered counsellors, requires knowledge on theories of personality and psychotherapy, able to practice assessment and intervention techniques, and discover the dynamics of human behavior (Corey, 2011). 
While SSSthe work to understand the issue and provide necessary information often lies on the hand of a counsellor, group counselling on the other hand, requires both counsellor and members of the group to work together in decision-making and addressing the issues. In individual counselling, the settings often involve dual-interaction between the counsellor and a client. In group counselling settings, it involves two or more individuals to communicate, interact and explore similar concerns or issues in a psychotherapy conversation. An effective group counselling session are able to provide members in the group with a place to give and receive feedback, to gain insight into interpersonal aspect and to address problems that they faced in life. It is an excellent choice for numerous intrapersonal and interpersonal issues and has been designed for all kinds of settings today for many types of groups (Corey, Corey, \& Corey, 2014).

The history of group counselling has its own antiquity where the exact origin is abstruse, but the more established procedures and guidance was evolved with the rise of psychotherapy. One of the earliest documented review on group therapy was in the early 1900 s when a Boston physician, Dr. Joseph

$\mathrm{H}$. Pratt began to use a directive-teaching methodology to treat patient with tuberculosis on the effectiveness of hygiene and cleanliness (Berg, Landreth, \& Fall, 2018). Despite his initial approach was a time-saving expedient, it received positive feedbacks and was widely copied (Hadden, 1955). The success of group therapy began to spread its wings when Alfred Adler and J.L Moreno used the methods in Europe to counsel children and individuals from all background respectively (Berg et al, 2018). Following Moreno's definition of "group psychotherapy" in 1932, group therapies and counselling began to create a phenomenal acceptance during World War II when the understaffed military hospital were forced to adopt group treatment measures due to the acceleration of numbers for psychiatric casualties (Scheidlinger, 2004).

In 1942, S.R Slavson established American Group Psychotherapy Association (AGPA), dedicated to explore group psychotherapy practice and research, publishes the International journal for Group Psychotherapy (Berg et al, 2018). The proliferation of group counselling began to grow in the year 1960-1970s with a more in-depth discussion on its procedure and methodology to promote an ethical measure in handling members of the group. Association for Specialist in Group Work (ASGW) was formed in 1973 as a division of American Counselling Association to promote training standards and ethical guidelines for group counsellors (Bert et al, 2018). In Malaysia, it is unclear on how the group counselling make it ways, however counselling in general began as a school guidance focusing on the vocational intervention in 1960s. Persatuan Kaunseling Malaysia or PERKAMA was established in 1980s where at the same time Ministry of Education announced the need for guidance and counselling teachers in school due to the rise of substance abuse among youth in Malaysia, together with government-sponsored drug counselling (See \& Ng, 2010). Like any other counselling sessions, it is important for counsellor to navigate the counselling through psychotherapy theory to deliver the input and output throughout the session.

Theory is an important aspect of counselling, as it helps the counsellor conceptualize and make sense of the countless pieces of information learned from the client (Berg et al, 2018). According to Yusni Mohamad Yusop et al. (2020), group counselling have been proven give positive effects to group members based on various issues. The issues that found in that research included the psychological and physical aspect of life such as anxiety, depression, anger repression, Premenstrual Syndrome of women, and internet addictive. Besides, group counselling also able to help people using time-sharing method in a least time (Yusop et al., 
2020). In group counselling, theory act as a navigational instrument to help set a direction on where you are starting out, where you hope to end and the steps along the way (Corey et al, 2014). Members of a counselling group are guided to understand the interpersonal nature of their problems, and provide the support and necessary treatment or intervention honest selfexploration. Cognitive behavior theory or CBT, for example, allow members of a group to be involved in a self-exploration on behavior, cognitions and emotions through teaching and learning process (Corey, 2012).

$\mathrm{CBT}$, as the name suggest, is a form of learning therapy that combine both cognitive and behavioral principles to change disruptive and dysfunctional behaviors, emotions and thoughts. It is a directive, time- limited, structured approach used to treat a variety of interpersonal issues and mental health disorders (Fenn \& Bryne, 2013). The concept of CBT includes Behavior Therapy, Cognitive Therapy, Rational Emotive Behavior Therapy and Reality Therapy, Mindfulness based Cognitive Therapy and many more. According to Corey et all, 2014, although the approach is diverse, they share common attributes of (i) it is a collaborative relationship between members of the group and the counsellor (ii) the psychological distress is a disturbance in cognitive process and (iii) it realise on empirical validation of its concepts and techniques. CBT includes a wide range of techniques or homework that members of the group can use to develop skills and achieve their personal goals during the counselling session.

The role of counsellor in CBT's group counselling is a directive and focused, emphasizing acceptance of each members (Berg et al, 2018). The counsellor requires to listen, teach and encourage each member to identify irrational thinking or behavior. Counsellor will assume an active role and utilized activity-oriented experiences in the group and provide assignments as homework as an activity outside the group settings. Previous studies show that CBT has been used widely in group counseling to help groups of clients. Accordingly, this paper will address on:

- the effectiveness of Cognitive Behavioral Therapy on various issues in the group counselling settings.

\section{Methodology}

The electronic database from Universiti Putra Malaysia that reviewer used was Science Direct as a primary literature search to find the journal articles for the purpose of this study. Firstly, key in the keyword term which were "cognitive behavioral therapy" and "group counselling" as the beginning of searching process. After that, as shown in Table 1 and 2, inclusion and exclusion criteria were specified in order to select the appropriate journal articles. Initially, 475 journal articles were identified using the keywords "cognitive behavioral therapy" and "group counselling". Reviewer started to look more on document type which is article. The number of results found was decreased by keyword "effectiveness" and "effects". Then, reviewer selected the main subject areas to focused on which were Psychology, Social Science and Art and Humanities. 
INTERNATIONAL JOURNAL OF ACADEMIC RESEARCH IN BUSINESS AND SOCIAL SCIENCES Vol. 10, No. 9, 2020, E-ISSN: 2222-6990 ㄷ 2020 HRMARS

Table 1.Inclusion Criteria of the Systematic Review

\begin{tabular}{llll}
\hline $\begin{array}{l}\text { Inclusion Criteria } \\
\text { Presented in Order }\end{array}$ & Particulars & $\begin{array}{l}\text { Literatures } \\
\text { Identified }\end{array}$ & $\begin{array}{l}\text { Remaining } \\
\text { Literatures }\end{array}$ \\
\hline Key terms & $\begin{array}{l}\text { Cognitive Behavioral } \\
\text { Therapy, Group Counselling }\end{array}$ & 475 & 475 \\
Document type & Article & 348 & 348 \\
Subject area & $\begin{array}{l}\text { Psychology, Social } \\
\text { Science, Art and Humanities } 37\end{array}$ & 37 \\
Keyword & Effectiveness, Effects & 29 & 29 \\
\hline
\end{tabular}

The reviewer narrow down the search results, the search area were excluded the Medicine, Business, Management and Accounting, Economics and Finance, Engineering, Health Professions and also the literature review article. The search was stopped when 10 most relevant journal articles was found. The articles were reviewed and summarized thoroughly. 
Table 2.Exclusion Criteria of the Systematic Review

\begin{tabular}{|c|c|c|c|}
\hline $\begin{array}{l}\text { Exclusion Criteria } \\
\text { Presented in Order }\end{array}$ & Particulars & $\begin{array}{l}\text { Literatures } \\
\text { Identified }\end{array}$ & $\begin{array}{l}\text { Remaining } \\
\text { Literatures }\end{array}$ \\
\hline Inclusion Criteria & & & 37 \\
\hline Subject area & $\begin{array}{l}\text { Medicine, Business, } \\
\text { Management and Accounting, } \\
\text { Economics and Finance, } \\
\text { Engineering, Health Professions }\end{array}$ & 29 & 29 \\
\hline Article type & Review Article & 12 & 17 \\
\hline
\end{tabular}

Figure 1: Flow diagram for selective review of studies on the effectiveness of cognitive behavioral therapy in group counselling

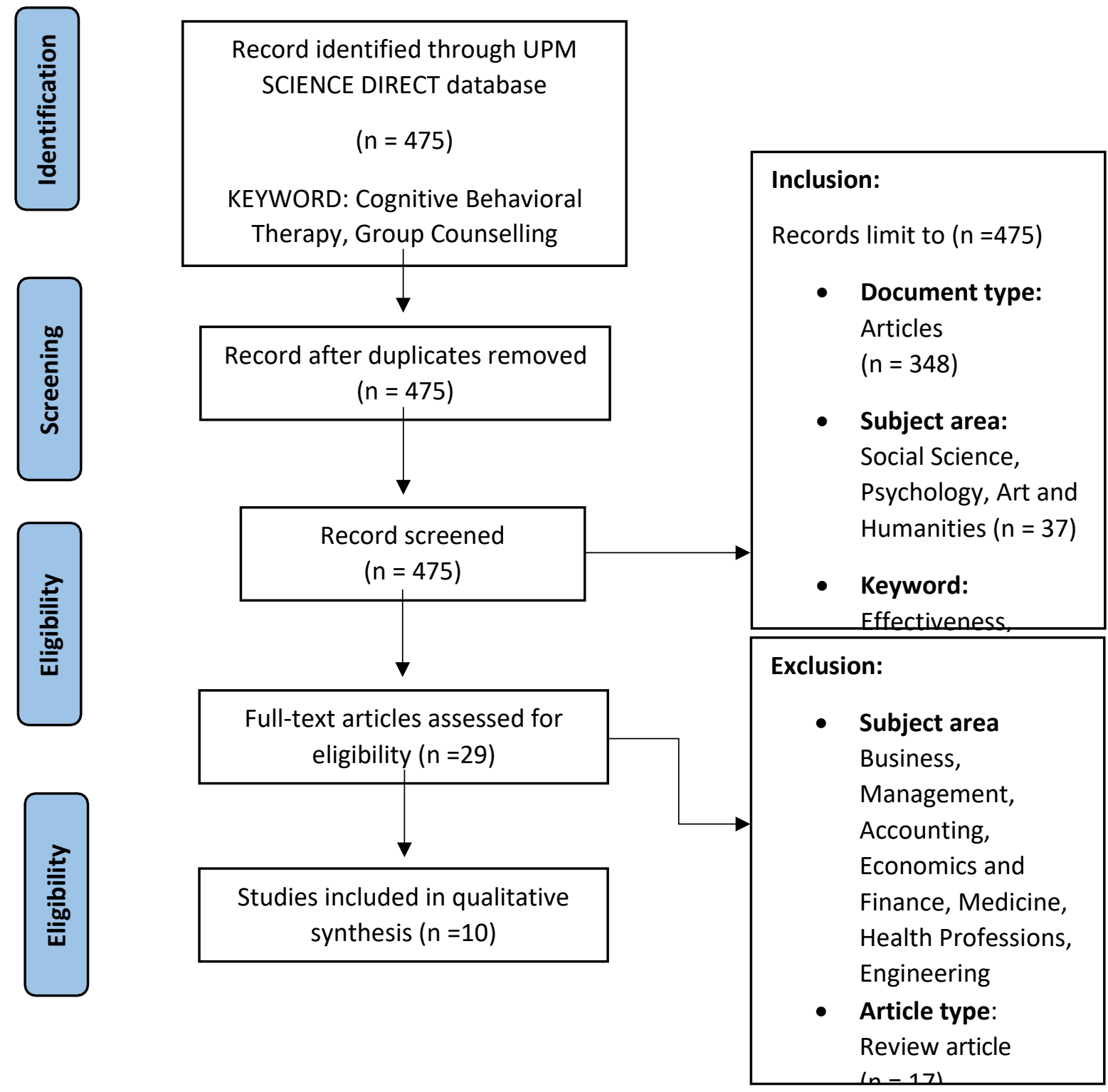


This systematic review is conducted by using electronic databases namely Science Direct. The search term used is "Cognitive Behavioral Therapy", "Group Counselling" and other relevant derivations. The flow diagram is depicted in Figure 1. There were 475 papers found related to the key terms in the search. Then, reviewer screened the retrieved papers based on their titles and abstracts. Only 348 of the papers were selected due to the type of document. After filter based on subject area in psychology, social science and art and humanities, there only 37 articles found. Articles then narrowed down to 29 which included terms effectiveness and effects. This review also excluded articles from management, accounting, economics and finance, medicine, health professions and engineering. The type of article from review article were also excluded. Finally, 10 out of 17 articles were selected from different journal sources.

\section{Findings}

This paper will discuss on the article review on the effectiveness of applying CBT in group counselling. There are several issues that we can look upon, using CBT in group counselling. The summary of each articles can be found in this section.

Table 3: Selected article on the effectiveness of CBT in group counselling

\begin{tabular}{|c|c|c|c|}
\hline $\begin{array}{l}\text { Article } \\
\text { Author(s) }\end{array}$ & Title & Purpose of study & Findings \\
\hline $\begin{array}{l}\text { Larkin \& Thyer, } \\
1999\end{array}$ & $\begin{array}{l}\text { Evaluating cognitive- } \\
\text { behavioral group } \\
\text { counseling to improve } \\
\text { elementary school } \\
\text { students' } \\
\text { self-esteem, self- } \\
\text { control, and } \\
\text { classroom behavior }\end{array}$ & $\begin{array}{l}\text { Measure potential } \\
\text { effectiveness of } \\
\text { cognitive-behavioral } \\
\text { group counselling with } \\
\text { elementary school } \\
\text { student. }\end{array}$ & $\begin{array}{l}\text { Significant improvements on } \\
\text { self-esteem, perceived self- } \\
\text { control with encouraging } \\
\text { result on } \\
\text { groupmembers' effortto } \\
\text { maintain their learning } \\
\text { experience. }\end{array}$ \\
\hline $\begin{array}{l}\text { Siddle, Jones, \& } \\
\text { Awenat, } 2003\end{array}$ & $\begin{array}{l}\text { Group cognitive } \\
\text { behavior therapy for } \\
\text { anger: a pilot study }\end{array}$ & $\begin{array}{l}\text { Measure the } \\
\text { effectiveness of group } \\
\text { CBT for individual with } \\
\text { anger issues }\end{array}$ & $\begin{array}{l}\text { Reported to have reduction } \\
\text { in the incident related to } \\
\text { anger each month while the } \\
\text { perception on anger towards } \\
\text { themselves was } \\
\text { also reduced. }\end{array}$ \\
\hline $\begin{array}{l}\text { Piet, Hougaard, } \\
\text { Hecksher\& } \\
\text { Rosenberg, } 2010\end{array}$ & $\begin{array}{l}\text { A randomized pilot } \\
\text { study of mindfulness } \\
\text { - based cognitive } \\
\text { therapy and group } \\
\text { cognitive- behavioral } \\
\text { therapy for young } \\
\text { adults } \\
\text { with social phobia. }\end{array}$ & $\begin{array}{l}\text { Treatment towards } \\
\text { young adults with social } \\
\text { phobia using } \\
\text { randomized control } \\
\text { group mindfulness- } \\
\text { based cognitive therapy } \\
\text { (MBCT) and } \\
\text { group cognitive- }\end{array}$ & $\begin{array}{l}\text { MCBT is a useful, low cost } \\
\text { treatment to treat social } \\
\text { phobia, however, it is less } \\
\text { effective compared to CBT. }\end{array}$ \\
\hline
\end{tabular}


behavior therapy

(CBT).

\begin{tabular}{|c|c|c|c|}
\hline $\begin{array}{l}\text { Ahmad \& Salim, } \\
2011\end{array}$ & $\begin{array}{l}\text { The effect of } \\
\text { psychological } \\
\text { intervention in } \\
\text { reducing disciplinary } \\
\text { cases among } \\
\text { Malaysian } \\
\text { secondary school } \\
\text { students }\end{array}$ & $\begin{array}{l}\text { Group based CBT to } \\
\text { reduce disruptive } \\
\text { behavior among school } \\
\text { students }\end{array}$ & $\begin{array}{l}\text { Positive impact on the level } \\
\text { of disciplinary problems. The } \\
\text { frequency of misbehavior in } \\
\text { the treatment group } \\
\text { dropped when compared to } \\
\text { the control group. }\end{array}$ \\
\hline $\begin{array}{l}\text { Karami, } \\
\text { Ghasemzadeh, } \\
\text { Saadat, } \\
\text { Mazaheri, \& } \\
\text { Zandipour, } 2012\end{array}$ & $\begin{array}{l}\text { Effects of group } \\
\text { counseling with } \\
\text { cognitive-behavioral } \\
\text { approach on reducing } \\
\text { divorce } \\
\text { children's } \\
\text { depression }\end{array}$ & $\begin{array}{l}\text { Aims to use group- based } \\
\text { CBT to measure its } \\
\text { effectiveness on } \\
\text { depression in children } \\
\text { with divorced parent. }\end{array}$ & $\begin{array}{l}\text { According to this study, } \\
\text { group-based CBT for children } \\
\text { with divorced parent prove } \\
\text { to have an influence to } \\
\text { decrease children's } \\
\text { depression. }\end{array}$ \\
\hline $\begin{array}{l}\text { Nazari, Birashk, } \\
\text { \& } \\
\text { Ghasemzadeh, } \\
2012\end{array}$ & $\begin{array}{l}\text { Effects of group } \\
\text { counseling with } \\
\text { cognitive-behavioral } \\
\text { approach on reducing } \\
\text { psychological } \\
\text { symptoms of } \\
\text { Premenstrual } \\
\text { syndrome (PMS) }\end{array}$ & $\begin{array}{l}\text { Evaluate how group CBT } \\
\text { approach in group } \\
\text { counselling may } \\
\text { decrease psychological } \\
\text { and physical symptom of } \\
\text { PMS. }\end{array}$ & $\begin{array}{l}\text { The authors did not share } \\
\text { the details of the study } \\
\text { thorough, there is a } \\
\text { significance value on how } \\
\text { group-based CBT reduces the } \\
\text { psychological and physical } \\
\text { symptoms of PMS }\end{array}$ \\
\hline $\begin{array}{l}\text { Palmstierna, } \\
\text { Haugan, } \\
\text { Jarwson, } \\
\text { Rasmussen, \& } \\
\text { Nøttestad, } 2012\end{array}$ & $\begin{array}{l}\text { Cognitive-behavior } \\
\text { group therapy for men } \\
\text { voluntary seeking help } \\
\text { for intimate partner } \\
\text { violence. }\end{array}$ & $\begin{array}{l}\text { Measure the } \\
\text { effectiveness of cognitive } \\
\text { behavioral therapy (CBT) } \\
\text { in a group counselling to } \\
\text { reduce domestic violence } \\
\text { by the male partner. }\end{array}$ & $\begin{array}{l}\text { There was a significantly } \\
\text { lower rate of physical } \\
\text { violence of participants } \\
\text { reported in the treatment } \\
\text { group compared to the } \\
\text { waiting list group. }\end{array}$ \\
\hline $\begin{array}{l}\text { Ueda \& Tsuda, } \\
2013\end{array}$ & $\begin{array}{l}\text { Differential outcomes } \\
\text { of skill training, group } \\
\text { counselling, and } \\
\text { individual cognitive } \\
\text { therapy for persons } \\
\text { with acquired visual } \\
\text { impairment }\end{array}$ & $\begin{array}{l}\text { The research focuses } \\
\text { outcomes of skills } \\
\text { training program with } \\
\text { and without cognitive } \\
\text { therapy in group and } \\
\text { individual counselling for } \\
\text { persons with acquired } \\
\text { visual } \\
\text { impairment in Japan. }\end{array}$ & $\begin{array}{l}\text { The outcome of the study } \\
\text { showed that participants } \\
\text { with low psychological } \\
\text { distress decreased anxiety } \\
\text { and increased acceptance of } \\
\text { disability }\end{array}$ \\
\hline
\end{tabular}




\begin{tabular}{|c|c|c|c|}
\hline $\begin{array}{l}\text { Ayub, Nasir, } \\
\text { Kadir, \& } \\
\text { Mohamad, } 2015\end{array}$ & $\begin{array}{l}\text { Cognitive Behavioral } \\
\text { Group Counselling in } \\
\text { Reducing Anger and } \\
\text { Aggression among } \\
\text { Male Prison Inmates } \\
\text { in Malaysia }\end{array}$ & $\begin{array}{l}\text { To examine the } \\
\text { effectiveness of group- } \\
\text { based CBT on anger and } \\
\text { aggression among male } \\
\text { prison inmates in } \\
\text { Malaysia }\end{array}$ & $\begin{array}{l}\text { Significant increase in anger } \\
\text { control as well reduction of } \\
\text { aggression in the } \\
\text { intervention group }\end{array}$ \\
\hline $\begin{array}{l}\text { Bagherian- } \\
\text { Afrakoti, } \\
\text { Alipour, } \\
\text { Pourasghar, \& } \\
\text { Shirvani, } 2018\end{array}$ & $\begin{array}{l}\text { Assessment of the } \\
\text { efficacy of group } \\
\text { counselling using } \\
\text { cognitive approach on } \\
\text { knowledge, attitude, } \\
\text { and decision making of } \\
\text { pregnant women } \\
\text { about modes of } \\
\text { delivery }\end{array}$ & $\begin{array}{l}\text { Study the effectiveness } \\
\text { of cognitive group } \\
\text { counselling for pregnant } \\
\text { women on knowledge, } \\
\text { attitude and decision } \\
\text { making on mode of } \\
\text { delivery. }\end{array}$ & $\begin{array}{l}\text { The knowledge of delivery } \\
\text { modes and attitude on } \\
\text { vaginal birth has significantly } \\
\text { increased in the group } \\
\text { consultation as compared to } \\
\text { the control group. }\end{array}$ \\
\hline
\end{tabular}

\section{Summary of Articles}

Summary Article 1: Evaluating cognitive-behavioral group counseling to improve elementary school students' self-esteem, self-control, and classroom behavior Introduction

Youth with behavioral issues has become a major concern in educational and societal settings. Due to the disruption that may happened in the class, this inappropriate behavior not only consume teacher's time and attention but also influence by other students. While students with worrying behaviors may not meet criteria for psychiatric condition, the action alone may contribute to disciplinary action or mental health referral. In order to provide necessary intervention, sources of disruptive behavior must be identified. According to the article, some of the sources may came from psychological and environmental issue. The study was conducted to measure potential effectiveness of cognitive-behavioral group counselling with elementary school students.

Methodology

The study focuses on two elementary schools in rural and city area with thirty-two and twenty students respectively. Fifty-two elementary school students were identified by teachers, parents or voluntary involvement for protocol-based cognitive-behavioral group counselling. Four instruments were used to conduct this study, i) Rosenberg Self-Esteem Scale (RSEA), to measure self-esteem, (ii) Children's Perceived Self-Control Scale (CPSCS), to measure children's perception of their self-control, (iii) teacher's grade on students' behavior before and after the group intervention, (iv) teacher's aides' grade on student behavior before and after the group intervention. The group counselling sessions were conducted on the interval of one hour per week for eight weeks, involving 10-11 students for each group. The study was reviewed and approved by the Human Subjects Review Committee, University of Georgia Institutional Review Board.

The group counselling was structured around cognitive-behavioral approaches such as problem-solving strategies, self-instruction, modelling, role play, alternative thinking, social skills training and covert imagery. Throughout the eight sessions, several protocols were introduced as follows: 
Session 1 Structuring, established ground rules, introduction of each members and preview students' commitment on housework

Session 2 Uses memory activity tools, discussion on homework, identification of problematic behaviors(s), encourage relationship between members and instilling positive reinforcements.

Session 3 Introduction and exploration on the topic of anger; discussion on factors that contribute to anger, identify ways to deal productively on anger, reflection and homework on behaviors related to anger.

Session 4 Review the previous assignment, review on their reflection on anger and how it impacted themselves and others, role play on a certain situation, group leader introduced cognitive-behavioral approaches in handling anger, homework on model students' forappropriate behavior.

Session 5 Review the preview assignment, discussion with group members on their thoughts, feelings, and expectation on model students' behavior., identification the number of positive connections in educational settings, the discussion on do's and don'ts to establish and maintain appropriatebehaviorand positive connection, role play, homework on more do's on behavior and connection.

Session 6 Review the previous assignment, discussion on personal strengths and develop a continued goal attainment plan as their homework.

Session 7 Discussion and sharing session on each of group member's goals, discussion over the belief and ideas on new behavior and actions, identified additional models for good behavior that they would like to make connection with, homework on recognizing individual's value after attended the counselling sessions.

Session 8 The final session focused on compiling all the information that they had learned where the group leader reminded everyone the positive aspects during the course of the counselling, positive reinforcement activity and a final activity of their choice.

\section{Results}

The finding from the article shows there are significant improvements on self-esteem, perceived self-control with encouraging result on group members effort to maintain their learning experience. The result of this study suggests early intervention using group cognitivebehavioral approaches for disruptive behavior would bring positive impact on youth at a lowcost measure. The service can be readily integrating the schools' settings, however, the article 
suggested similar study with a long-term follow-up should be done before it can be suggested to be an intervention to keep behavioral disruptive children out of the criminal justice system.

\section{Summary Article 2: Group cognitive behavior therapy for anger: a pilot study Introduction}

Individuals with issue on anger may contribute to unhealthy relationship within career, marital, property and others. The traditional approach for individual with anger issues, has often based stress inoculation approach that focuses on monitoring anger outburst, identifying the relationship between events and thinking process as well as controlling the anger. That being said however, cognitive behavioral therapy (CBT) offers attempts to guide the discovery to challenge thoughts and belief. While there were concerns over drop up and unwillingness to engage with the sessions, the study focuses on whether the participants for a group cognitive behavioral therapy would benefit from the session.

Methodology

Participants for the study were selected from patients who routinely referred professional help. Prior to the selection, participants were invited to attend a screening interview and was asked to complete State-Trait Anger Expression Inventory (STAXI) to measure between the experience of state and trait anger. One-hour group session for six weeks were conducted that includes similar contents each week, (i) Structuring, (ii) Feedback from last week's session (iii) Homework review, (iv) Discussion on the topic, (v) Homework for next week, (vi) Feedback. A post therapy interview was also conducted within two weeks of the last session as a follow up.

\section{Results}

Initially, 119 potential participants between 16 and 65 years old was referred however, after interview and several concerns over the lack of commitment, only 34 participants attended at least one sessions of the therapy and eleven participants attended the all six group sessions. The authors concluded that there is a significant change in anger traits, control of anger, and the expression of anger. Participants reported to have reduction in the incident related to anger each month while the perception on anger towards themselves was also reduced. The study suggests that the right CBT intervention with a short duration may be a factor for the result.

\section{Summary Article 3: A randomized pilot study of mindfulness-based cognitive therapy and group cognitive-behavioral therapy for young adults with social phobia.} Introduction

Social phobia or social anxiety disorder can be characterized by a marked and persistence fear of social or performance situation in which may exposed to unfamiliar people or possible scrutiny by others. This article suggests that only $5-10 \%$ of persons with social phobia received treatment. The authors cited Kessler (2013), indicating that individual age 15 to 25 years old has been considered critical for the development of social impairment and comorbid disorders, thus, early intervention is needed. While CBT is an effective measure for social phobia disorder, the 
authors agree there is a need for further development of social phobia treatment due to clinical trial ran by Hofmann \& Bögels (2006) and Rodebaugh et al. (2004) indicated $40-50 \%$ patients with social phobia referred to CBT show little or no improvement. The authors later suggested that mindfulness-based assessment may be a potentially useful alternative for individuals with social phobia. MBCT is a form of cognitive therapy, reported to have a significant reduction in symptoms of stress, anxiety and depression. It is possible that a combination of mindfulness and CBT might lead to a better result than monotherapy, since the two methods focus on different aspects of social phobia maintenance mechanisms.

Methodology

The research focuses on treating young adults with social phobia using randomized control group mindfulness-based cognitive therapy (MBCT) and group cognitive-behavior therapy (CBT). Twenty-six young adults of 18-25 years whom clinically diagnosed of anxiety disorder were selected for this study. Participants were recruited via announcement made by the website of Anxiety Clinic, a newspaper advertisement, a pamphlet and contacts from the Student Counselling Center and the Clinic for Anxiety and OCD in Denmark. The participants were randomly selected into two groups, (i) fourteen participants received eight two-hour sessions of group MCBT and, (ii) twelves participants received twelve two-hour sessions of group CBT over the period of 19 months.

In Group CBT, treatment includes a) psycho-education on social phobia and CBT, (b) analysis of each experience, (c) cognitive restructuring and (d) exposure on behavior. Homework were given after each session. In group MCBT, the sessions focused on mindfulness meditation techniques such as the body scan, gentle mindful yoga exercises, and sitting meditation as homework, participants were recommended to spend 30-40 minutes daily on practices of mindfulness.

Results

Five data points were measured namely, (i) prior to therapy, (ii) after participants' first treatment, (iii) after their second treatment; and at follow-ups of (iv) six months; and (v) 12 months after end of treatment. The participants were general satisfied with both treatments with almost similar result in all measurement. As a result, MCBT is a useful, low cost treatment to treat social phobia, however, it is less effective compared to CBT.

\section{Summary Article 4: Evaluating cognitive-behavioral group counselling to improve elementary school students' self-esteem, self-control, and classroom behavior} Introduction

The recurring disciplinary issues among students in Malaysia's educational settings has heighten over the years. The majority issue came from students in secondary schools with reported behavior on truancy, impolite behavior, criminal behavior and wasting time. According to the authors, several studies have revealed, the students who were involved in disciplinary problem may have lack of social skills and poor academic performance which may lead into civil offender in the future. Cognitive behavioral approaches is introduce to be an important technique to help replacing maladaptive behavior.

\section{Methodology}

90 students aged 16 years old from three secondary schools in Selangor were identified for this study. The selected schools possess similar socio-demographic characteristics. Although the method of students' identification was not being revealed, it is stated that most of the students have average academic achievements. The schools' offences that were committed by the 
students were truancy (44\%) and not being neatly dressed (27.8\%). Other offences were below $10 \%$ respectively on impoliteness, vandalism and smoking. The students were divided into three groups; (i) control group whereby students would attend normal procedure at school, (ii) treatment group that received individual intervention group (iii) treatment group that received intervention in a group session. Mann-Whitney $U$ test was used to compare differences between the control and treatment groups.

Results

Psychological intervention has brought a positive impact on the level of disciplinary problems. The frequency of misbehavior in the treatment group dropped when compared to the control group. The authors believed the intervention can be used by guidance and counseling teachers to help counselling the students with concerned behavior.

\section{Summary Article 5: Effects of group counseling with cognitive-behavioral approach on reducing divorce children's depression}

Introduction

Children required a healthy environment for them to grow. In the case of separation of their parent, children faced many psychological problems due to their negative reaction against separation and the societal environment. This may interrupt their interpersonal growth and functioning in the society. Depression, for example, is one of the psychological disorders that may affect children due to the separation. Although one of the interventions for depression in adult is CBT, there is limited study on the effectiveness of CBT in children, let alone children with divorced parent. This study aims to use group-based CBT to measure its effectiveness on depression in children with divorced parent.

\section{Methodology}

Twenty children from two residential welfare in Tehran, Iran were selected for this study. The children were divided into two groups, (i) ten children in the intervention group and (ii) ten children in the control group. Prior to the selection, the children were asked to do pre-test for children depression questionnaire (CDI) to measure their depressed stage. The intervention group received an hour session every week for 8 sessions. Two weeks of the training sessions ends, a post-test with the same questionnaire were given to both groups. The group counselling session were content were as follows:

\begin{tabular}{ll}
\hline Session 1 & $\begin{array}{l}\text { Structuring, self-introduction, ground rules and setting up the information on } \\
\text { the group counselling. }\end{array}$ \\
\hline Session 2-7 & $\begin{array}{l}\text { Children were given trainings and information on negative thoughts, cognitive } \\
\text { errors, self-esteem, controlling anger assertiveness and solving problem. } \\
\text { Homework were given at each week and were discussed in the next session. }\end{array}$ \\
\hline Session $\mathbf{8}$ & $\begin{array}{l}\text { The trainings were reviewed in the last session. The children were given } \\
\text { psychoeducation at the end of the session. }\end{array}$ \\
\hline
\end{tabular}

Results

According to this study, group-based CBT for children with divorced parent prove to have an influence to decrease children's depression. That being said however, the authors suggested a suitable problem solving and decision-making method should be used to help individuals use 
their abilities when encounter problem, discover appropriate solutions and believe in their weakness and strength.

\section{Summary Article 6: Effects of group counseling with cognitive-behavioral approach on reducing psychological symptoms of Premenstrual syndrome (PMS)}

Introduction

A health sexual and reproductive health in women includes menstruation, an important role to keep their life balance. However, women have also experience Premenstrual syndrome (PMS), which affects mental and physical condition. This study aims to evaluate how CBT approach in group counselling may decrease psychological and physical symptom of PMS.

\section{Methodology}

The study involved female staff aged 25 to 45 years old in Iran University of Science and Technology. Over thirty-four voluntary participants agree to be part of the study. The study was conducted into two separate group, (i) seventeen participants in the invention group and (ii) seventeen participants in the control group. The invention group received a two-hour sessions per week for 10 session. A follow up session was discussed after two months.

Results

Although the authors did not share the details of the study thorough, there was a significance value on how group-based CBT reduces the psychological and physical symptoms of PMS. It seems that the awareness of PMS using CBT proven to improve psychological safety, alleviate stress and enhancing self-confidence.

\section{Summary Article 7: Cognitive-behavior group therapy for men voluntary seeking help for intimate partner violence.}

Introduction

Violence is a prevalent issue among male-female partners in domestic settings. It hinders female security to feel safe and intimate with their partner. There are several programs that were conducted around cognitive behavioral approach including couple counselling, neuropsychological treatment, dialectical counselling and many more. While the treatment focuses on the victim, this study focuses on the preparatory, mainly man who abuse their female partner. The study aims to measure the effectiveness of cognitive behavioral therapy (CBT) in a group counselling to reduce domestic violence by the male partner. The authors described domestic violence is defined as the use of physical violence, verbal aggression or material violence that cause harm, injury and fear.

\section{Methodology}

The participants were scouted by advertisement in public media and the spread of information via general practitioners in Trondheim, Norway. Within 12 months, thirty-seven men were voluntary recruited fora screening interview. However, only twenty-six individuals participated, with fifteen belong to the immediate treatments group and eleven participants belonged to the waiting list group as a control group. The participants began their journey in individual counselling to familiar with the process. After the sessions, participants were divided into group of six to eight members in each group, and received a two-hour session for 15 weeks. The therapy was based on Aaron Beck's cognitive therapy. 
The sessions were divided into two stages. The first stage (seven to eight sessions), focuses on behavioral modification phase and the second stage (seven to eight sessions), focuses on the cognition modification phases. At the end of the 15 sessions, the group members evaluate each other and identify areas to improve in the future.

Results

There was a significantly lower rate of physical violence of participants reported in the treatment group compared to the waiting list group. While the participants in the waiting list group wishes to change their behavior, they are unable to do so by themselves, therefore, the result showed that a 15 weeks group session on CBT-based program is effective with significantly reduce self-reported violent behavior.

\section{Summary Article 8: Differential outcomes of skill training, group counselling and individual cognitive therapy for persons with acquired visual impairment Introduction}

A person with acquired visual impacted may suffer various psychological issue due the prejudice, discrimination and limitation to function in everyday settings. The research focuses outcomes of skills training program with and without cognitive therapy in group and individual counselling for persons with acquired visual impairment in Japan. Over 37 adults' participants in an intervention-based group and 42 adults participate in a control-based group, ranging from 20 to 65 years old and 19 to 75 years old respectively.

There is a lack of evidence on what is the most beneficial psychotherapy for clients with acquired visual impartment. It is undeniable cognitive therapy seems to be effective for depressed clients' rehabilitation process. The authors cited Dodds, Ferguson, Ng, Flannigan, Hawes, and Yates (1994) that proposed cognitive therapy and attribution retraining would be beneficial, although they did not have empirical data about its effectiveness for clients with acquired visual impairment.

\section{Methodology}

In this study, two groups were identified; (i) intervention group; 37 adults with acquired visual impartment that participated in the Living Skills Training Programme, a project to help persons with acquired visual impairment to live comfortably and adapt skills in everyday setting. The participants were placed participants' psychological distress at Fukuoka National Rehabilitation Center in Japan from November 2003 to March 2003. Participants in this group engaged in skills training program with either group counselling or skills training program with group counselling and individual therapy, (ii) control group; 42 adults in a similar Living Skills Training Programme in Kobe and Shiobara National Rehabilitation Centre who do not receive group counselling or individual therapy.

The research used several instruments such as The Profile of Mood Status (PMOS), Total Mood Disturbance (TMD), The Nottingham Adjustment Scale Japanese Version were used to evaluate participants' psychological distress and psychological adjustment to their disability. The data collection begins with pretest 2 weeks after the participants entered the centre while posttest was given approximately 2 weeks before graduating from the centre.

Participants in intervention group were participate in group counselling and individual therapy once per week respectively. The purpose of the counselling using cognitive therapy were explained throughout the sessions. In group counselling, there are three component that were discussed; (i) talking about experiences and feelings, (ii) psycho-education on 
disability, information on eye diseases and the social resources for the participants, and (iii) stress reduction technique including relaxation and meditation. For individual therapy, 9 out of 19 selected participants with high psychological distress participate in the session.

Results

The outcome of the study showed that participants with low psychological distress decreased anxiety and increased acceptance of disability, even when they did not participate in group counselling. However, among the participants with high distress, they did not show any improvement without group counselling or individual therapy.

The participants with high distress who engaged in group counselling showed an improving trend in attitudes toward others. Moreover, the participants who chose to engage in individual therapy in addition to group counselling showed decreased tension-anxiety, depression, and fatigue, and significantly improved acceptance of disability. These results suggest that group counselling, combined with individual cognitive therapy, can be an effective part of rehabilitation treatment for clients who have high psychological distress.

\section{Summary Article 9: Cognitive Behavioral Group Counselling in Reducing Anger and Aggression among Male prison Inmates in Malaysia}

Introduction

Anger, motivates behavior and can be useful for pursue goals, exercise self-protection and assertion. However, anger can also be a tool for intensified negative reactions and feelings. Anger is often associated with variety of negative action that often came with negative psychosocial and interpersonal consequences. It is also linked to vulnerable physical illness such as stoke, pain, hypertension and coronary heart disease. According to the authors, in the prison settings, treatment for anger and aggression should be developed as it benefits inmates and the environment. One of the treatments for anger management is using cognitive behavioral intervention. In Malaysian Prisons, intervention on anger and aggressiveness using group- based CBT has not being fully implemented. This study aims to examine the effectiveness of group- based CBT on anger and aggression among male prison inmates in Malaysia.

Methodology

220 male inmate's ages around 22 to 61 years old were selected by prison officers and required to go through a screening process using State-Trait Anger Expression inventory-2 (STAXI-2) and Aggression Questionnaire (AQ) to determine their anger experience and aggression. Based on the score, 80 participants with a highest score of STAXI-2 and AQ were selected to participate in the group sessions. The participants were assignment into two groups, (i) 40 participants for the experimental group and (ii) 40 participants for the control group. In the experimental group, the participants received a total of eight session of group-based CBT with a span of two hours session, two time per week. The control group had been placed as a waiting list and only started their group session after the end of the experimental group. The sessions for the group-based CBT were as follows: 


\begin{tabular}{|l|l|}
\hline Session 1 & Structuring, Introduction and rapport building \\
\hline Session 2 & Overview of anger and aggression \\
\hline Session 3 & $\begin{array}{l}\text { Events and cues of anger, and the aggression } \\
\text { cycle }\end{array}$ \\
\hline Session 4 & Anger control plans \\
\hline Session 5 & Cognitive restructuring \\
\hline Session 6 & Assertiveness training \\
\hline Session 7 & Conflict resolution model \\
\hline Session 8 & Review and termination \\
\hline
\end{tabular}

Results

The findings for this study indicated that there was a significant increase in anger control as well reduction of aggression in the intervention group. The authors suggest that group-based CBT was effective in reducing anger and aggression among the inmate and contributed to help managing their emotion and behavior appropriately. The improvement has also maintained for two months after the invention ends.

Summary Article 10: Assessment of the efficacy of group counselling using cognitive approach on knowledge, attitude, and decision making of pregnant women about modes of delivery

Introduction

Tin mode of delivery for women on the mode of delivery is a subjective process. It is influence by the culture, perceptions, beliefs, attitude and knowledge. In some culture, the existing education program for pregnant women came from the advices from the caregivers that may overlook the needs of the pregnant women. Therefore, the consultation towards having voluntary and information decision on mode of delivery is important. This article is looking to study the effectiveness of cognitive group counselling for pregnant women on knowledge, attitude and decision making on mode of delivery.

Methodology

This article draws from a semi experimental study on pregnant women to in Sari, Iran. Several assessments were done for the group counselling session. Potential participants were provided questionnaires on mothers' knowledge on vagina birth and caesarean delivery and attitudes on such matter. Seventy participants with criteria of gestation period between 24 and 32 weeks, tendency to do caesarean delivery or uncertain mode of birth, minimum high school education, wanted pregnancy, no history of infertility, have yet to participate in a child birth preparation classes and no maternal or fetal indications for caesarean deliveries. The participants were divided into two main groups; (i) thirty-five women in the intervention group, and (ii) thirty- five women in the control group (conventional education).

Using Aaron Back's cognitive theory, the intervention group received eight counselling session in 90-minute settings. 


\begin{tabular}{|c|c|}
\hline Session & Brief description \\
\hline One & $\begin{array}{l}\text { Structuring, ground rules, explanation on commitment and } \\
\text { homework Introduction on cycle of thoughts, feelings, and } \\
\text { behaviors in various situations. }\end{array}$ \\
\hline Two & $\begin{array}{l}\text { Review on previous session. Explanation and discussion on the } \\
\text { negative automatic thoughts and how to recognize them, as well } \\
\text { as information on recording feelings and thoughts. Homework on } \\
\text { the thinking pattern and } \\
\text { identify feelings and thoughts. }\end{array}$ \\
\hline Three & $\begin{array}{l}\text { Review of the homework and further discussion over the previous } \\
\text { topic. }\end{array}$ \\
\hline $\begin{array}{l}\text { Four to } \\
\text { seven }\end{array}$ & $\begin{array}{l}\text { Discussion over the identifying negative thoughts on vaginal birth and } \\
\text { lead the leader lead the group to challenge negative thoughts } \\
\text { pertaining the mode } \\
\text { of delivery. As homework, the participants require to complete the } \\
\text { form and find positive response for each session. }\end{array}$ \\
\hline Eight & Conclusion and evaluation of the program. \\
\hline
\end{tabular}

Mann-Whitney $U$ and Chi-square was also used to compare demographic and obstetrics characteristic between the group, together with t-test for knowledge and attitude and McNemar test for decision-making understanding.

Results

There was a loss of seven participants in the intervention group due to irregular attendance and obstetrics problems while there is no loss in the control group. The data was tabulated for sixty-three women (twenty-eight woman in the intervention group and thirty five women in the control group). The knowledge of delivery modes and attitude on vaginal birth has significantly increased in the group consultation as compared to the control group.

\section{Discussion}

Based on the review, Cognitive Behavioral Therapy (CBT) is proved to be an effective intervention for group counselling with different kind of issues. From the articles that been reviewed, most of the cognitive behavioral therapy were used to overcome problems such as anxiety, anger management, depression, traumatic disorder, social phobia, disruptive behavior, externalizing and internalizing disorders. The participants that involved in group counselling came from various types of background and with different range of age.

The main aims the use of Cognitive Behavioral Therapy in group was to heighten individual awareness and adapt, their unhelpful cognitions which would impact on their emotional responses and then on their behavior. From the articles reviewed above, we can see that cognitive behavioral therapy is one of effective intervention in reducing anger. Uncontrolled anger issue may also lead to unhealthy relationship within career, marital, property and others. According to Ayub, Nasir, Kadir, and Mohamad (2015) stated that intervention groupbased CBT was effective in controlling anger and reducing aggression among the male prison inmate and it helps them to be in positive reactions and feelings. In addition, Siddle, Jones, and Awenat (2003) also mentioned that throughout the group session by using CBT intervention there are significant change on how the perceived an anger that including anger traits and the expression of anger. 
Some traumatic event might be the main factor that create anxiety for an individual and lead to negative emotion. The anxiety such as phobia may influence daily routine and be the barrier for development of social life. Based on Piet, Hougaard, Hecksher and Rosenberg (2010) mMinfulness and group CBT treatment is a potential alternative to reduce symptoms of stress, anxiety and depression It supported the research by Karami, Ghasemzadeh, Saadat, Mazaheri, and Zandipour (2012) on effects of group counseling with cognitive-behavioral approach on reducing divorce children's depression. This research found that, group-based CBT prove to have an influence to decrease children's depression after two week sessions. According to Ueda and Tsuda (2013), the person with visual impairment who engage with cognitive behavioral intervention in individual therapy and also group counselling showed improvement on acceptance of disability, decreased tension-anxiety, depression, and fatigue. Cognitive behavioral therapy is quite popular intervention to control anxiety, depression, and behavior and build healthy thought (Yusop et al., 2020).

The benefit of Cognitive Behavioral Therapy in group counselling also reduce disruptive behavior while increase their self-esteem and self-control which affect their behavior of students in school setting. There are positive impact on the level of disciplinary problems among the school students by using CBT technique to help replacing maladaptive behavior (Ahmad \& Salim, 2011). Besides that, Larkin \& Thyer (1999) found that self-esteem and perceived self-control with encouraging result on group members' effort also show the improvement using the CBT intervention. The research by Palmstierna, Haugan, Jarwson, Rasmussen, and Nøttestad (2012) also showed that cognitive behavioral therapy technique in group session helps to lower rate of physical violence of participants. CBT in group counselling session is proven contributed to help managing their emotion and behavior appropriately.

Moreover, cognitive behavioral therapy intervention in group session also helps women to handle their personal and internal issues. As we know, women become more sensitive and experienced on mood changes before menstruation and sometimes it is hard for them to endure it. Based on Nazari, Birashk, and Ghasemzadeh (2012), they stated that the participant become less stress after get some awareness on PMS syndrome from discussion and word encouragement from group members. In other research, it is showed that the pregnant women that join cognitive behavioral group counselling session be more confidence on vaginal birth decision (Bagherian-Afrakoti, Alipour, Pourasghar, \& Shirvani, 2018). The pregnant women gain group consultation about the knowledge on delivery and attitude on vaginal birth by the group members. Therefore, this CBT intervention proved that it helps women to increase psychological and physical endurance in overcoming their issues such as premenstrual syndrome and decision making on delivery modes.

\section{Conclusion}

Based on the articles review, CBT seems to be an effective approach to do in group counselling. In various situation, whether anger management issues, depression or pregnancy plan, CBT approach provide a framework to understand the potential in clients to help creating changes in him. It is also proved that support from the members in the group session also helps in making the group counselling session become more effective. The limitation however, the group members can engage in catastrophic thinking by choosing to dwell in their worst-case scenario. Hence, the counsellor requires to have an excellent mediation skill to counter maladaptive behavior. Rather than various issues, future research could focus only on one issue using CBT in group counseling. Therefore, the selected issue 
would be discussed more details along with more interesting results. Future researcher should also refer to the latest articles which is more updated. Research may widen the search too from numerous data bases. By doing so, it might help researcher to access more articles and draw more data.

\section{References}

Ahmad, A., \& Salim, S. (2011). The effect of psychological intervention in reducing disciplinary cases among Malaysian secondary school students. Procedia - Social and Behavioral Sciences, 30, 2592-2596. doi:10.1016/j.sbspro.2011.10.507

Ayub, N., Nasir, R., Kadir, N. B., \& Mohamad, M. S. (2015). Cognitive Behavioral Group Counselling in Reducing Anger and Aggression among Male Prison Inmates in Malaysia. Asian Social Science, 12(1), 263. doi:10.5539/ass.v12n1p263

Corey, G. (2011). Theory and practice of counseling and psychotherapy. 9th ed. Australia; Belmont, CA: Thomson/Brooks/Cole

Corey, G. (2012). Theory and Practice of counseling and psychotherapy, 9th ed.

Corey, M. S., Corey, G., \& Corey, C. (2014). Groups: Process and practice. Belmont, CA: Brooks/Cole, Cengage Learning

Fenn, K., \& Byrne, M. (2013). The key principles of cognitive behavioral therapy. InnovAiT: Education and Inspiration for General Practice, 6(9), 579585. doi:10.1177/1755738012471029

Hadden, S. B. (1955). Historic Background of Group Psychotherapy. International Journal of Group Psychotherapy, 5(2), 162-168. doi:10.1080/00207284.1955.11508583

Ivey, A. E., \& Ivey, M. B. (2014). Intentional interviewing and counseling: Facilitating client development in a multicultural society. Belmont, CA: Thomson Brooks/Cole.

Karami, S., Ghasemzadeh, A., Saadat, M., Mazaheri, E., \& Zandipour, T. (2012). Effects of Group Counseling with Cognitive-Behavioral Approach on Reducing Divorce Children's Depression.Procedia - Social anBehavioral Sciences, 46, 77-81. doi:10.1016/j.sbspro.2012.05.072

Nazari, N. H., Birashk, B., \& Ghasemzadeh, A. (2012). Effects of group counseling with cognitive- behavioral approach on reducing psychological symptoms of Premenstrual syndrome (PMS). Procedia - Social and Behavioral Sciences, 31, 589-592. doi:10.1016/j.sbspro.2011.12.109

Palmstierna, T., Haugan, G., Jarwson, S., Rasmussen, K., \& Nøttestad, J. A. (2012). Cognitivebehavior group therapy for men voluntary seeking help for intimate partner violence. Nordic Journal of Psychiatry, 66(5), 360-365. doi:10.3109/08039488.2012.665080

Piet, J., Hougaard, E., Hecksher, M. S., \& Rosenberg, N. K. (2010). A randomized pilot study of mindfulness-based cognitive therapy and group cognitive-behavioral therapy for young adults with social phobia. Scandinavian Journal of Psychology. doi:10.1111/j.1467-9450.2009.00801.x

Scheidlinger, S. (2004). Group Psychotherapy and Related Helping Groups Today: An Overview. American Journal of Psychotherapy, 58(3), 265-280. doi:10.1176/appi.psychotherapy.2004.58.3.265

See, C. M., \& Ng, K. (2010). Counseling in Malaysia: History, Current Status, and Future Trends. Journal of Counseling \& Development, 88(1), 18-

22.doi:10.1002/j.1556-6678.2010.tb00144.x

Siddle, R., Jones, F., \& Awenat, F. (2003). Group Cognitive Behavior Therapy For Anger: A Pilot Study. Behavioral and Cognitive Psychotherapy, 31(1), 69-83. 
doi:10.1017/s1352465803001073.

Ueda, Y., \& Tsuda, A. (2013). Differential outcomes of skill training, group counseling, and individual cognitive therapy for persons with acquired visual impairment. Japanese Psychological Research, 55(3), 229-240. doi:10.1111/

Yusop, Y. M., Zainudin, Z. N., Ahmad, N. A., Othman, W. N. W., Surat, S., \& Fung, W. S. (2020). The effectiveness of group counselling: A systematic review. Journal of Critical Review, 7(13). doi: http://dx.doi.org/10.31838/jcr.07.13.94 